\title{
Serum Irisin Level as a Predictive marker for Hemodinamically Significant Patent Ductus Arteriosus in Premature Infants with Gestational Age of 32 Weeek or Less
}

Erbu Yarci $^{1}$, Ufuk Cakir ${ }^{1}$, Aslihan Kose Cetinkaya ${ }^{1}$, Handan Asilhan Unsal ${ }^{2}$, Cuneyt Tayman ${ }^{1}$.

${ }^{1}$ Zekai Tahir Burak Women's Health Education and Research Hospital, Neonatology, Ankara, Turkey.

${ }^{2}$ Zekai Tahir Burak Women's Health Education and Research Hospital, Pediatric Cardiology, Ankara, Turkey.

Background: Diagnosis and treatment of patent ductus arteriosus(PDA) in premature infants is still an important problem for clinicians. Echocardiography is the gold standart for determination of PDA based on clinical and hemodynamic significance. Clinical decision making may be aided by measuring circulating biomarkers such as brain natriuretic propeptid and a newly myokine Irisin.

Objective: We aimed to invastigate the significance of serum Irisin and B-type natriuretic peptide (BNP) in the diagnosis and follow-up of hemodinamically significant PDA (hsPDA) in very low birth weight infants with gestational age 32 weeks or less.

Method: In this study 43 premature infants with gestational age less than 32 weeks were included . 21 premature infants with hsPDA were determined as study group and 22 premature infants without PDA were assigned as the control group. Blood samples were collected and analyzed for serum Irisin and proBNP levels.

Table 1. Demographic and clinical characteristics of the groups

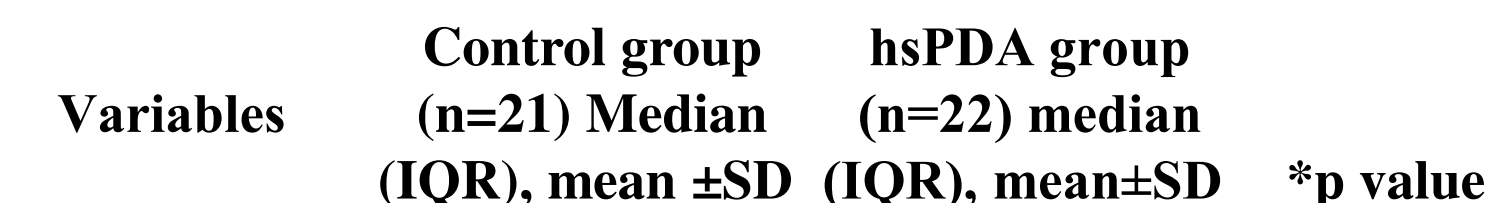

\begin{tabular}{|c|c|c|c|}
\hline $\begin{array}{l}\text { Gestational } \\
\text { age(wk) }\end{array}$ & $29.4(3)$ & $27.9(3)$ & 0.006 \\
\hline Birth weight & $1240 \pm 240$ & $1095 \pm 325$ & 0.04 \\
\hline $\begin{array}{l}\text { APGAR 1st } \\
\text { minute }\end{array}$ & $6.0(1)$ & $5.0(1)$ & 0.0001 \\
\hline $\begin{array}{l}\text { APGAR 5th } \\
\text { minute }\end{array}$ & $8.0(1)$ & $7.0(2)$ & 0.0001 \\
\hline $\begin{array}{l}\text { Mechanical } \\
\operatorname{ventilation}(d)\end{array}$ & $1(1)$ & $5(6)$ & 0.0001 \\
\hline $\begin{array}{l}\text { Duration of } \\
\text { nCPAP (d) }\end{array}$ & $3(4)$ & 610 & 0.0001 \\
\hline $\begin{array}{l}\text { Duration of } \\
\text { oxygen (d) }\end{array}$ & $4.5(4)$ & $7(8)$ & 0.033 \\
\hline $\begin{array}{l}\text { Pro-BNP } \\
(\mathrm{pg} / \mathrm{ml})\end{array}$ & $2739 \pm 2253$ & $25750 \pm 10872$ & 0.0001 \\
\hline İrisin (ng/ml) & $0.69 \pm 0.30$ & $1.41 \pm 0.48$ & 0.0001 \\
\hline
\end{tabular}

Results: Serum levels of pro-BNP and Irisin in the study group at the time of diagnosis of PDA were found to be significantly higher than the control group, and the levels decreased significantly after medication. Multivariate regression analysis showed that birth weight and the presence of PDA were significantly correalted with serum Irisin levels.

Conclusion: Irisin and pro-BNP assays have clinical importance in the diagnosis, initiation of therapy and follow, response to therapy in very low birth weight infants with PDA.

Table 2. Median (IQR) of pro-BNP and endocan before and after medication of PDA

\begin{tabular}{|c|c|c|c|}
\hline & $\begin{array}{l}\text { Before PDA } \\
\text { medication } \\
\text { median } \\
(\text { IQR })\end{array}$ & $\begin{array}{l}\text { After PDA } \\
\text { medication } \\
\text { median (IQR) }\end{array}$ & $p$ value \\
\hline $\begin{array}{l}\text { Pro BNP } \\
(\mathrm{pg} / \mathrm{ml})\end{array}$ & $25750(10872)$ & $4782(3256)$ & 0.0001 \\
\hline $\operatorname{Irisin}(\mathrm{ng} / \mathrm{ml})$ & $1.41 \pm 0.48$ & $1.02 \pm 0.36$ & 0.0001 \\
\hline
\end{tabular}

Abbreviations: BNP, B-type natriuretic peptide; IQR, interquartile range;PDA, patent ductus arteriosus.

$* p<0.05$ Statistically significant 